\title{
FAKTOR-FAKTOR YANG MEMPENGARUHI PERMINTAAN CABAI RAWIT DI KOTA TOMOHON
}

\author{
Yosi Ratag \\ Paulus A. Pangemanan \\ Lorraine W. Th. Sondak
}

\begin{abstract}
The study aims to analyze the factors that affected demand of cayenne pepper in Tomohon city. This study conducted for 3 months from September to November 2017. Data used secondary data was time series data per quarter from year 2012 to 2016. Analysis used is multiple regression analysis. The result showed that factor of, cayenne pepper price, substitution goods (curly pepper) and complementary goods (shallots) significantly affected on cayenne pepper demand.*ir*.
\end{abstract}

Keywords: demand, cayenne pepper, Tomohon City.

\begin{abstract}
ABSTRAK
Penelitian ini bertujuan untuk menganalisis faktor-faktor yang mempengaruhi permintaan cabai rawit di Kota Tomohon. Penelitian ini dilakukan selama 3 bulan dari September sampai November 2017. Data yang digunakan adalah data sekunder yaitu data time series per kwartal tahun 2012-2016. Analisis yang digunakan adalah analisis regresi berganda. Hasil penelitian menunjukan bahwa variabel bebas yang meliputi harga cabai rawit, harga barang substitusi (cabai keriting) dan harga barang komplementer (bawang merah) secara bersama-sama berpengaruh nyata pada permintaan cabai rawit di Kota Tomohon.*Ir*.
\end{abstract}

Kata kunci: permintaan, cabai rawit, Kota Tomohon.

\section{PENDAHULUAN}

\section{Latar Belakang}

Sektor pertanian merupakan sektor yang mendapatkan perhatian dari pemerintah karena peranannya yang sangat penting dalam pembangunan ekonomi jangka panjang maupun dalam rangka pemulihan ekonomi bangsa. Sektor pertanian juga dapat menjadi basis dalam mengembangkan kegiatan ekonomi perdesaan melalui pengembangan usaha berbasis pertanian yaitu agribisnis dan agroindustri. Dengan pertumbuhan yang terus positif secara konsisten, sektor pertanian berperan besar dalam menjaga laju pertumbuhan ekonomi nasional (Antara, 2009).

Salah satu komoditas hortikultura adalah cabai rawit. Cabai rawit merupakan tanaman yang di butuhkan di masyarakat baik sebagai bahan penyedap masakan, tanaman kesehatan, bahkan sebagai mata pencaharian. Cabai rawit juga mengandung zat-zat gizi yang sangat diperlukan untuk kesehatan manusia.

Cabai rawit benar-benar merupakan komoditas sayuran yang sangat merakyat. Tak heran bila volume peredaran cabai dipasaran sangat banyak jumlahnya. Mulai dari pasar rakyat, pasar swalayan, warung pinggiran, 
hingga pabrik mie instan sehari-harinya membutuhkan cabai dalam jumlah yang tidak sedikit. Untuk saat ini permintaan cabai di tinggat nasional masih dipenuhi pasokan cabai dari daerah sentra produksi dan mengimpor dari luar negeri apabila terjadi kekurangan produksi (Prajnanta, 2004).

Permintaan terhadap cabai untuk kebutuhan sehari-hari dapat berfluktuasi, yang disebabkan karena naik turunnya harga cabai yang terjadi di pasar eceran. Fluktuasi harga yang terjadi di pasar eceran, selain disebabkan oleh faktor-faktor yang mempengaruhi sisi permintaan. Kota Tomohon adalah salah satu kota dimana masyarakatnya dominan mengkonsumsi cabai, sehingga dapat dikatakan permintaan cabai akan terus ada meskipun harga cabai mengalami peningkatan yang cukup tinggi. Di Kota Tomohon sering di temui bahwa harga cabai kadang tinggi dan kadang rendah bahkan cenderung tidak menentu, Karena alasan tersebut maka penulis tertarik untuk mengadakan penelitian tentang faktor-faktor yang mempengaruhi permintaan cabai rawit di Kota Tomohon.

\section{Rumusan Masalah}

Berdasarkan latar belakang, maka yang menjadi permasalahan utama dalam penelitian ini adalah faktor-faktor apa yang mempengaruhi besarnya permintaan komoditi cabai rawit di Kota Tomohon dan berapa besar pengaruh faktor-faktor tersebut terhadap permintaan komoditi cabai di Kota Tomohon.

\section{Tujuan Penelitian}

1. Untuk mengetahui faktor-faktor yang mempengaruhi permintaan komoditi cabai rawit Kota Tomohon.

2. Untuk menganalisis pengaruh faktor-faktor tersebut terhadap permintaan komoditi cabai rawit di Kota Tomohon.

\section{Manfaat Penelitian}

Diharapkan agar hasil penelitian ini dapat memberikan gambaran mengenai kondisi permintaan cabai rawit di Kota Tomohon dan dapat mengembangkan pengetahuan mengenai permintaan.

\section{METODE PENELITIAN}

\section{Waktu dan Tempat Penelitian}

Penelitian ini di lakukan selama tiga bulan yaitu sejak bulan September sampai bulan November 2017 dan berlokasi di Pasar Beriman Tomohon, Dinas Pertanian serta Badan Pusat Statistika Kota Tomohon.

\section{Metode Pengumpulan Data}

Data yang di gunakan dalam penelitian ini adalah sekunder. Data sekunder yang digunakan dalam penelitian yaitu sumber data time series per kwartal dari tahun 2012 - 2016 per 4 bulan yang di peroleh dari instansi terkait (Badan Pusat Statistika Kota Tomohon) serta dari berbagai buku dan literatur yang berkaitan dengan penelitian ini.

\section{Konsep Pengukuran Variabel}

Dalam penelitian ini variabel yang di ukur adalah:

1. Permintaan cabai rawit adalah cabai rawit yang di konsumsi oleh masyarakat di Kota Tomohon selama 5 tahun (2012-2016) kg/tahun diukur per kwartal.

2. Harga cabai rawit di Kota Tomohon selama 5 tahun (2012-2016) Rp/kg.

3. Harga barang substitusi dalam hal ini adalah harga cabai keriting di Kota Tomohon selama 5 tahun (2012-2016) $\mathrm{Rp} / \mathrm{kg}$.

4. Harga barang pelengkap dalam hal ini bawang merah (2012-2016) Rp/kg.

\section{Metode Analisis Data}

Metode Analisis data dilakukan dalam analisis data ini adalah regresi linier berganda dengan menggunakan bantuan program SPSS versi 21.0. Untuk dapat menjelaskan pengaruh variabel tidak bebas secara simultan dan secara parsial terhadap variabel bebas dijelaskan melalui koefisin determinasi.

\section{Regresi Linier Berganda}

Metode analisis data yang digunakan dalam penelitian ini adalah analisis data dimana data yang dikumpulkan disajikan dalam bentuk table dan untuk mengetahui 
faktor-faktor yang mempengaruhi harga cabai di gunakan analisis regresi linier berganda. Analisis regresi linier berganda merupakan studi ketergantungan dari suatu variabel tak bebas atau dependen variabel (Y) pada suatu variabel bebas atau independen variabel $(\mathrm{X})$ dengan tujuan meramalkan dan

memperkirakan nilai dari variabel tak bebas jika variabel bebas sudah di ketahui. Berikut rumus persamaan regresi linier berganda :

$$
\mathrm{Y}=\beta 0+\beta 1 \mathrm{X} 1+\beta 2 \mathrm{X} 2+\beta 3 \mathrm{X} 3+\varepsilon
$$

Keterangan:

Y : Jumlah Permintaan Cabai

B0 : Bilangan Konstanta

$\beta 1 \mathrm{X1}$ : Harga cabai rawit

$\beta 2$ X2 : Harga bahan Pelengkap (Bawang Merah)

$\beta 3$ X3 : Harga Bahan Pengganti (Cabai Merah)

\section{Pengujian Secara Simultan (Uji F)}

Uji $F$ merupakan pengujian hubungan regresi secara simultan yang bertujuan untuk mengetahui apakah seluruh variabel independen bersama-sama mempunyai pengaruh yang signifikan terhadap variabel dependen (Sugiyono, 2012).

\section{Pengujian Secara Parsial (Uji t)}

Uji t digunakan untuk menguji hipotesis secara parsial guna menunjukkan pengaruh tiap variabel independen secara individu terhadap variabel dependen. Uji $\mathrm{t}$ adalah pengujian koefisien regresi masing-masing variabel independen terhadap variabel dependen untuk mengetahui seberapa besar pengaruh variabel independen terhadap variabel dependen (Sugiyono, 2012).

\section{Koefisien determinasi $\left(\mathbf{R}^{2}\right)$}

Koefisien determinasi digunakan untuk mengetahui seberapa besar hubungan dari beberapa variabel dalam pengertian yang lebih jelas. Koefisien determinasi akan menjelaskan seberapa besar perubahan atau variasi suatu variabel bisa dijelaskan oleh perubahan atau variasi pada variabel yang lain
(Santosa \& Ashari, 2005). Dalam bahasa sehari-hari adalah kemampuan variabel bebas untuk berkontribusi terhadap variabel tetapnya dalam satuan persentase.

Nilai koefisien ini antara 0 dan 1 , jika hasil lebih mendekati angka 0 berarti kemampuan variabel-variabel independen dalam menjelaskan variasi variabel amat terbatas. Tapi jika hasil mendekati angka 1 berarti variabel-variabel independen memberikan hampir semua informasi yang dibutuhkan untuk memprediksi variasi variabel dependen.

\section{HASIL DAN PEMBAHASAN}

\section{Keadaan Alam Kota Tomohon}

Tomohon merupakan dataran tinggi dengan ketinggian rata-rata 786 meter di atas permukaan laut. Pusat Kota Tomohon terletak pada posisi 0118 ' 51" Lintang Utara dan 124 49' 40" Bujur Timur. Luas wilayah Kota Tomohon adalah 147,21 $\mathrm{km}^{2}$. Pada tahun 2016 curah hujan diukur di 5 titik yaitu di kantor Balai Penyuluh Pertanian Perikanan dan Kehutanan di masing-masing kecamatan Tomohon Selatan Tomohon Tengah Tomohon Timur Tomohon Barat dan Tomohon Utara. Hujan yang turun di Kota Tomohon paling banyak mengguyur Kecamatan Tomohon Barat pada bulan Desember dengan curahhujan sebesar 512,00 mm3. Sedangkan Kecamatan Tomohon Timur paling sering mengalami hujan pada bulan Mei dengan hari hujan sebanyak 26 hari (BPS Tomohon 2017).

Gambaran Umum Wilayah menjelaskan kondisi umum Kota Tomohon yang mencakup: kondisi fisik, kependudukan, administratif, keuangan dan perekonomian daerah, kebijakan penataan ruang, struktur organisasi serta tugas dan tanggung jawab perangkat daerah. Kota Tomohon dapat dicapai dengan menggunakan transportasi darat, jarak dari ibukota Provinsi Sulawesi Utara, Kota Manado $\pm 25 \mathrm{~km}$. Dari Bandara International Sam Ratulangi $\pm 34 \mathrm{~km}$, dan 
dari Pelabuhan International Bitung $\pm 60 \mathrm{~km}$ melalui Kabupaten Minahasa Utara dan Minahasa Induk. Jarak dari Kabupaten Minahasa Induk $\pm 15 \mathrm{~km}$ dan Kabupaten Minahasa Selatan $\pm 58 \mathrm{~km}$. Letak wilayah Kota Tomohon dari sebelah utara berbatasan dengan Kecamatan Pineleng dan Tombulu (Kabupaten Minahasa), sebelah Selatan berbatasan dengan Kecamatan Sonder dan Remboken (Kabupaten Minahasa) dan Kecamatan Tombariri (Kabupaten Minahasa), sebelah Barat dengan Kecamatan Tombariri dan sebelah Timur dengan Kecamatan Airmadidi (Kabupaten Minahasa Utara).

\section{Keadaan Penduduk Kota Tomohon}

Sumber utama data kependudukan adalah sensus penduduk yang dilaksanakan setiap sepuluh tahun sekali. Sensus penduduk telah dilaksanakan sebanyak enam kali sejak Indonesia merdeka, yaitu tahun 1961, 1971, 1980, 1990, 2000, dan 2010. Di dalam sensus penduduk, pencacahan dilakukan terhadap seluruh penduduk yang berdomisili di wilayah teritorial Indonesia termasuk warga negara asing kecuali anggota korps diplomatik negara sahabat beserta keluarganya. Metode pengumpulan data dalam sensus dilakukan dengan wawancara antara petugas sensus dengan responden dan juga melalui e-census. Pencatatan penduduk menggunakan konsep usual residence, yaitu konsep di mana penduduk biasa bertempat tinggal. Bagi penduduk yang bertempat tinggal tetap dicacah di mana mereka biasa tinggal, sedangkan untuk penduduk yang tidak bertempat tinggal tetap dicacah di tempat di mana mereka ditemukan petugas sensus pada malam 'Hari Sensus'. Termasuk penduduk yang tidak bertempat tinggal tetap.

Penduduk Tomohon berdasarkan proyeksi penduduk tahun 2016 sebanyak 101.981 jiwa yang terdiri atas 51.381 jiwa penduduk laki-laki dan 50.595 jiwa penduduk perempuan. Dibandingkan dengan proyeksi jumlah penduduk tahun 2015, penduduk Tomohon mengalami pertumbuhan sebesar 1,60 persen. Sementara itu besarnya angka rasio jenis kelamin tahun 2016 penduduk lakilaki terhadap penduduk perempuan sebesar 101,56. Kepadatan penduduk di Kota Tomohon tahun 2016 mencapai 692 jiwa/ $/ \mathrm{km}^{2}$. Kepadatan Penduduk di 5 kecamatan cukup beragam dengan kepadatan penduduk tertinggi terletak di kecamatan Tomohon Tengah dengan kepadatan sebesar 2.470 jiwa $/ \mathrm{km}^{2}$ dan terendah di Kecamatan Tomohon Barat sebesar 364 jiwa $/ \mathrm{km}^{2}$.

\section{Pertumbuhan Penduduk}

Laju pertumbuhan penduduk Kota Tomohon di pengaruhi oleh jumlah kelahiran, jumlah kematian, dan imigrasi yang terjadi di daerah tersebut. Kota Tomohon dalam angka yang menunjukkan persentase pertambahan penduduk dalam jangka waktu tertentu.

\begin{tabular}{|c|c|c|c|c|c|}
\hline \multirow{2}{*}{ Kecamatan } & \multicolumn{3}{|c|}{ Jumlah Penduduk } & \multicolumn{2}{|c|}{ Laju Pertumbuhan } \\
\hline & $2010 \mathrm{~S}$ & D 2015 & 2016 & $2010-2015$ & 2015-2016 \\
\hline Tomohon Selatan & 21.062 & 22.725 & 23.014 & 7,90 & 1,27 \\
\hline Tomohon Tengah & 20.156 & 22.756 & 23.251 & 12,90 & 2,18 \\
\hline Tomohon Timur & 10.269 & 10.875 & 10.972 & 5,90 & 0,89 \\
\hline Tomohon Barat & 14.160 & 14.740 & 14.822 & 4,10 & 0,56 \\
\hline Tomohon Utara & 25.906 & 29.277 & 29.922 & 13,01 & 2,20 \\
\hline Tomohon & 91.553 & 100.373 & 101.980 & 9,63 & 1,60 \\
\hline
\end{tabular}

Dari Tabel 1 dapat diketahui bahwa jumlah penduduk kota keseluruhan pada akhir tahun 2016 berjumlah 101.980 jiwa, laju pertumbuhan penduduk tomohon utara terdapat peningkatan pada tahun 2010-2015 sebesar 13,01 dan pada akhir tahun 2016 sebesar 2,20 pada Kecamatan Tomohon Utara. Dengan adanya peningkatan jumlah penduduk di suatu kecamatan maka akan berpengaruh terhadap permnitaan cabai merah.

\section{Keadaan Penduduk Menurut Umur}

Keadaan penduduk menurut umur pada suatu daerah dapat di gunakan untuk mengetahui besarnya penduduk yang produktif dan angka beban tanggungan. Keadaan penduduk Kota Tomohon dapat di tampilkan pada Tabel 2. 


\begin{tabular}{|c|c|c|c|}
\hline \multirow{2}{*}{ Kelompok Umur } & \multicolumn{3}{|c|}{ Jenis Kelamin } \\
\hline & Laki-Laki & Perempuan & Total \\
\hline $0-4$ & 3.917 & 3.619 & 7.536 \\
\hline $5-9$ & 4.013 & 3.801 & 7.814 \\
\hline $10-14$ & 4.319 & 3.926 & 8.245 \\
\hline $15-19$ & 4.563 & 4.558 & 9.121 \\
\hline $20-24$ & 4.303 & 4.673 & 8.976 \\
\hline $25-29$ & 3.811 & 3.481 & 7.292 \\
\hline $30-34$ & 3.715 & 3.254 & 6.969 \\
\hline $35-39$ & 3.696 & 3.668 & 7.364 \\
\hline $40-44$ & 3.726 & 3.692 & 7.418 \\
\hline $45-49$ & 3.567 & 3.424 & 6.991 \\
\hline $50-54$ & 3.260 & 3.086 & 6.346 \\
\hline $55-59$ & 2.794 & 2.751 & 5.545 \\
\hline $60-64$ & 2.279 & 2.333 & 4.612 \\
\hline $65-69$ & 1.609 & 1.618 & 3.227 \\
\hline $70-74$ & 976 & 1.077 & 2.053 \\
\hline $75+$ & 838 & 1.634 & 2.472 \\
\hline Jumlah & 51.386 & 50.595 & 101.981 \\
\hline
\end{tabular}

Tabel 2 menunjukan bahwa presntase terbesar penduduk usia produktif yaitu terdapat pada jenis kelamin laki-laki yaitu 51.386 jiwa dari total jumlah penduduk 101.981 atau sebesar $2,59 \%$ presentase usia produktif. Keadaan menurut umur yang sebagian besar usia produktif memberikan gambaran mengenai kebutuhan akan zat gizi jika dibandingkan dengan penduduk belum produktif dan non produktif. Kebutuhan akan zat gizi dalam tubuh dapat dipenuhi melalui bahan pangan seperti sayuran yang salah satunya adalah cabai rawit. Cabai rawit mengandung banyak zat-zat gizi seperti protein , lemak, karbohidrat, kalsium (Ca), Fosfor (P), besi (Fe), Vitamin-vitamin, dan mengandung senyawa-senyawa alkaloid, seperti capsaicin, flavenoid, dan minyak esensial yang sangat diperlukan untuk kesehatan manusia, sehingga semakin besar penduduk usia produktif akan meningkatkan permintaan cabai rawit.

\section{Keadaan Penduduk Menurut Pendidikan}

Pendidikan merupakan salah satu indikator kemajuan masyarakat, apabila penduduk di suatu daerah telah mengenyam pendidikan, maka potensi untuk pengembangan daerah tersebut besar. Tingkat pendidikan di Kota Tomohon dapat di pengaruhi oleh beberapa hal yang dapat di lihat pada tabel APM dan APK sebagai berikut:
Tabel 3. Angka Partisipasi Murni (APM) dan Angka Partisipasi Kasar (APK) Menurut Jenjang Pendidikan Di Kota Tomohon Tahun 2017

\begin{tabular}{ccc}
\hline $\begin{array}{c}\text { Jenjang } \\
\text { Pendidikan }\end{array}$ & $\begin{array}{c}\text { APM } \\
\text { Angka Partisipasi } \\
\text { Murni }\end{array}$ & $\begin{array}{c}\text { APK } \\
\text { Angka Partisipasi }\end{array}$ \\
\hline SD & 83,74 & 98,77 \\
SMP/MTS & 85,49 & 109,07 \\
SMA/SMK & 71,55 & 89,83 \\
\hline
\end{tabular}

Sumber: Badan Pusat Statistik Kota Tomohon Tahun 2017

Dari Tabel 3 yang masuk dalam sensus hanya angka partisipasi menurut jenjang pendidikan SD, SMP/MTS, SMA/SMK, dari total jumlah penduduk yang melaksanakan jenjang pendidikan hanya sampai pada SMP/MTS. Jumlah ini memiliki angka yang paling besar, sehingga dapat dikatakan bahwa Kota Tomohon cukup baik karena sebagian besar penduduk tenlah mengenyam pendidikan dan banyak yang telah mengikuti program wajib belajar 9 tahu. Hal ini akan berdampak pada pola pikir penduduk yang cenderung lebih mudah menerima pengetahuan, khususnya dalam perbaikan gizi dan peningkatan kesehatan sehingga akan meningkatkan permintaan bahan pangan yang memiliki nilai gizi tinggi, dalam kaitanya dengan hal ini adalah cabai rawit yang merupakan salah satu sayuran yang mengandung banyak zat-zat gizi.

\section{Keadaan Penduduk Menurut Mata Pencaharian}

Keadaan mata pencaharian penduduk suatu daerah dipengaruhi oleh sumberdaya yang tersedia dari kondisi sosial ekonomi seperti keterampilan yang dimilik seperti, usia, jenis kelamin, tingkat pendidikan, lapangan pekerjaan dan modal yang tersedia. Keadaan penduduk Kota Tomohon meurut mata pencaharian yaitu:

Tabel 4. Keadaan Penduduk Kota Tomohon Menurut Mata Pencaharian

\begin{tabular}{lccc}
\hline \multicolumn{1}{c}{ Mata Pencaharian } & Laki-laki & Perempua & Jumlah \\
\hline Berusaha Sendiri Tanpa Bantua & 6.818 & 2.564 & 9382 \\
Buruh Tidak Tetap & 3.475 & 1.383 & 4858 \\
Buruh Tetap & 2.277 & 652 & 2929 \\
Karyawan / Pegaawai & 7.521 & 5644 & 13165 \\
Pekerja Bebas di Pertanian & 644 & 312 & 956 \\
Pekerja Bebas Tidak di Pertania & 4.098 & 374 & 4472 \\
Pekerja Tidak Di Bayar & 1.862 & 2432 & 4294 \\
\hline Jumlah & 26.695 & 13.361 & 40.056 \\
\hline Sumber: Badan Pusat Statistik Kota Tomohon Tahun 2017
\end{tabular}


Mata Pencaharian penduduk Kota Tomohon dapat digunakan untuk mengetahui kesejahteraan penduduknya. Dari Tabel 4 diketahui bahwa sebagian penduduk Kota Tomhon bermata pencarharian yang beragam dan posisi mata pencaharian penduduk tertinggi adalah kayawan / pegawai, seperti kita diketahui perkembangan Kota Tomohon cukup baik sehingga Kota Tomohon lebih banyak terdapat penduduk yang bermata pencaharian sebagai karyawan / pegawai di bandingkan petani, buruh, dan pekerjaan bebas maupun tidak bebas.

\section{Pembahasan Variabel Permintaan/Konsumsi Cabai Rawit}

Cabai merupakan salah satu komoditi yang paling dicari oleh masyarakat Kota Tomohon. Masyarakat Kota Tomohon sudah terkenal dengan masakan yang pedas atau bisa dikatakan masakan dengan menggunakan banyak cabai. Di musim dingin juga permintaan akan cabai meningkat karena ketika musim dingin tiba maka konsumen berkeinginan untuk mengkonsumsi makanan yang bersifat pedas yang bias menghangatkan tubuh dan menambah nafsu makan. Sehingga permintaan akan cabai menjadi salah satu variabel yang menentukan harga cabai di Kota Tomohon Sulawesi Utara.

Kota Tomohon ,jumlah penduduk sebanyak 101.981 jiwa. Dalam penelitian ini variabel yang pertama adalah permintaan terhadap cabai rawit. Untuk menentukan permitaan konsumen terhadap cabai, perlu di ketahui terlebih dahulu jumlah populasi pedagang cabai rawit di Kota Tomohon karena dengan mengetahui populasi akan lebih mempermudah untuk mengetahui jumlah permintaan, dan setelah itu mencari tahu total penjualan cabai setiap harinya.

Untuk jumlah pedagang khusus pedagang cabai rawit, pasar tradisional tomohon sebanyak 60 pedagang. Penelitian ini mengarah pada pedagang pengupul bahkan pedagang eceran (Pasar Kota Tomohon, 2016). Setelah mengetahui jumlah populasi pedagang, selanjutnya di tentukan sampel. Untuk menentukan sampel dari banyaknya populasi pedagang cabai rawit di Kota Tomohon maka di gunakan data dari BPS 2016.

Dari hasil perhitungan dengan menggunakan data dari BPS 2016 di dapatkan hasil sampel pedagang cabai di Kota Tomohon. Selanjutnya akan untuk mengetahui jumlah permintaan cabai di Kota Tomohon maka perlu di ketahui jumlah cabai Rawit $(/ \mathrm{kg})$ yang terjual setiap hari ada berapa banyak. Dari hasil wawancara peneliti dengan pedagang cabai di pasar Tradisional Kota Tomohon di peroleh hasil penjualan setiap hari sebanyak $5-50 \mathrm{~kg}$ / hari.

Tabel 5. Pengelompokan Penjualan Cabai Rawit Dari Sampel Pada Pasar Tomohon

\begin{tabular}{cc}
\hline $\begin{array}{c}\text { Jumlah Sampel } \\
\text { (Pedagang) }\end{array}$ & $\begin{array}{c}\text { Jumlah Cabai yang } \\
\text { Terjual }(\mathrm{Kg})\end{array}$ \\
\hline 27 & $5-20$ \\
33 & $21-50$ \\
\hline
\end{tabular}

Sumber: Pasar Tradisional Kota Tomohon

Pada Tabel 5 dapat di ketahui bahwa pedagang yang menjual cabai rawit dengan penjualan $5-20 \mathrm{~kg}$ per hari sebanyak 27 pedagang, dan pedagang dengan penjualan 21 $50 \mathrm{~kg}$ per hari sebanyak 33 pedagang. Hal ini terjadi karena adanya penjualan yang terbagi atas di tipe pedagang hal ini dapat disebut sebagai pedagang kecil dan pedagan besar.

\section{Harga Cabai Rawit}

Harga cabai merah rawit adalah jumlah yang dibayarkan oleh penduduk untuk mendapatkan satu kilogram cabai. Komuditas utama Untuk menentukan permitaan konsumen terhadap cabai, perlu di ketahui terlebih dahulu jumlah populasi masyarakat Kota Tomohon karena dengan mengetahui populasi akan lebih mempermudah untuk mengetahui jumlah permintaan, dan setelah itu mencari tahu total penjualan cabai setiap harinya. Setelah mengetahui jumlah populasi, selanjutnya di tentukan sampel. Dalam penelitian ini cabai rawit merupakan komoditas utama dalam penelitian ini, Data yang di peroleh dari Dinas Perindustrian dan Perdagangan Provinsi Sulut bahwa harga cabai keriting di Kota Tomohon dapat dilihat pada Tabel 6 . 
Tabel 6. Harga Cabai Rawit Kota Tomohon

\begin{tabular}{ccc}
\hline Tahun & Bulan & $\begin{array}{c}\text { Harga Cabai Rawit } \\
\mathrm{Rp} / \mathrm{Kg}\end{array}$ \\
& & 62.000 \\
2012 & Januari & 60.000 \\
& Mei & 65.000 \\
\hline \multirow{3}{*}{2013} & September & 50.000 \\
& Januari & 30.000 \\
& Mei & 50.000 \\
\hline \multirow{2}{*}{2014} & September & 30.000 \\
& Januari & 50.000 \\
& Mei & 85.000 \\
\hline \multirow{3}{*}{2015} & September & 50.000 \\
& Januari & 50.000 \\
& Mei & 85.000 \\
\hline \multirow{3}{*}{2016} & September & 30.000 \\
& Januari & 32.000 \\
& Mei & 55.000 \\
\hline
\end{tabular}

Sumber: Dinas Perindustrian dan Perdagangan Provinsi Sulut

Tabel 6 menunjukan bahwa fluktuasi harga cabai rawit bergerak normal hal ini terlihat setiap 3 bulan dalam setahun yang telah di data oleh dinas perindustrian dan perdagangan. Fluktuasi ini juga dapat terjadi dikarenakan oleh adanya permintaan dan kebutuhan cabai rawit di Kota Tomohon.

\section{Harga Cabai Merah Keriting}

Harga cabai merah keriting dalam penelitian ini adalah jumlah yang dibayarkan oleh penduduk untuk mendapatkan satu kilogram cabai. Komuditas pengganti adalah komuditas yang dapat menggantikan fungsi komuditas lain sehingga harga komuditas pengganti dapat mempengaruhi permintaan komuditas yang dapat di gantikannya. Apabila harga komuditas utama meningkat maka penjual akan meningkatkan jumlah komuditas pengganti yang ditawarkan. Penjual berharap, konsumen akan beralih dari komuditas utama ke komuditas pengganti yang ditawarkan, karena harganya lebih rendah.

Barang pengganti adalah barang yang dapat menggantikan fungsi barang utama yang di perlukan ketika barang utama tersebut susah ditemukan atau harganya melonjak naik menyebabkan konsumen lebih memilih untuk menggunakan atau mengkonsumsi barang pengganti. Dalam penelitian ini cabai keriting dijadikan sebagai barang pengganti dari cabai rawit. Data yang di peroleh dari Dinas Perindustrian dan Perdagangan Provinsi Sulut bahwa harga cabai keriting di Kota Tomohon dapat dilihat pada Tabel 7.

Tabel 7. Harga Cabai Keriting Kota Tomohon

\begin{tabular}{ccc}
\hline Tahun & Bulan & $\begin{array}{c}\text { Harga Cabai Keriting } \\
\mathrm{Rp} / \mathrm{Kg}\end{array}$ \\
\hline \multirow{2}{*}{2012} & Januari & 30.000 \\
& Mei & 20.000 \\
& September & 17.500 \\
\hline \multirow{2}{*}{2013} & Januari & 15.000 \\
& Mei & 25.000 \\
& September & 25.000 \\
\hline \multirow{3}{*}{2014} & Januari & 40.000 \\
& Mei & 20.000 \\
& September & 44.000 \\
\hline \multirow{3}{*}{2015} & Januari & 30.000 \\
& Mei & 16.000 \\
& September & 45.000 \\
\hline \multirow{3}{*}{2016} & Januari & 40.000 \\
& Mei & 30.000 \\
& September & 27.000
\end{tabular}

Sumber: Dinas Perindustrian dan Perdagangan Provinsi Sulut

Tabel 7 menunjukan bahwa fluktuasi harga cabai keriting bergerak normal hal ini terlihat setiap 3 bulan dalam setahun yang telah di data oleh dinas perindustrian dan perdagangan. Fluktuasi ini juga dapat terjadi dikarenakan oleh adanya permintaan dan kebutuhan cabai keriting di Kota Tomohon.

\section{Harga Bawang Merah}

Bawang merah dikatakan sebagai barang komplementer jika barang tersebut digunakan secara bersama-sama atau pelengkap dengan barang lain, sehingga salah satu dari barang tersebut naik maka akan mempengaruhi banyaknya konsumsi barang komplementernya. Pada penelitian ini bawang merah diasumsikan sebagai barang komplementer daari cabai rawit. Bawang merah pada dasarnya mempunyai kegunaan yang sama dengan cabai merah keriting yaitu digunakan sebagai bumbu dapur atau masakan, sehingga kedua komoditi ini dapat digunakan secara bersamaan atau saling melengkapi untuk dijadikan bumbu masakan. Data yang di ambil dapat dilihat pada Tabel 8. 


\begin{tabular}{ccc} 
Tabel 8. Harga Bawang & $\begin{array}{c}\text { Merah di Kota } \\
\text { Tomohon }\end{array}$ & $\begin{array}{c}\text { Harga Bawang Merah } \\
\text { Rp/Kg }\end{array}$ \\
\hline Tahun & Bulan & 25.000 \\
& Januari & 25.000 \\
2012 & Mei & 20.000 \\
\hline \multirow{2}{*}{2013} & September & 20.000 \\
& Januari & 26.000 \\
& Mei & 30.000 \\
\hline \multirow{3}{*}{2014} & September & 25.000 \\
& Januari & 30.000 \\
& Mei & 30.000 \\
\hline \multirow{3}{*}{2015} & September & 30.000 \\
& Januari & 34.000 \\
& Mei & 30.000 \\
\hline \multirow{3}{*}{2016} & September & 30.000 \\
& Januari & 32.000 \\
& Mei & 55.000
\end{tabular}

Sumber: Dinas Perindustrian dan Perdagangan Provinsi Sulut

Tabel 8 menunjukan bahwa fluktuasi harga bawang merah cukup normal, memasuki akhir tahun 2016 sesuai data dari dinas perindustrian dan perdagangan provinsi sulawesi utara terjadi kenaikan yang cukup tinggi di bandingkan harga-harga sebelumnya.

Harga bawang merah dalam penelitian ini berada pada urutan ketiga dalam mempengaruhi permintaan cabai rawit di Kota Tomohon. Hal ini dapat dilihat dari nilai standart koefisien regresinya. Sedangkan berdasarkan hasil uji $\mathrm{F}$ dan $\mathrm{Uji} \mathrm{T}$ dapat diketahui bahwa harga bawang merah berpengaruh nyata terhadap permintaan cabai rawit. Oleh karna itu hipotesis dari penelitian ini yang menyatakan bahwa variabel harga bawang merah di duga berpengaruh terhadap permintaan cabai rawit di Kota Tomohon.

\section{Hasil Analisis Penelitian \\ Analisis Regresi Linear Berganda Menggunakan SPSS 21.0}

Analisis linear berganda digunakan untuk menentukan seberapa besar pengaruh simultan antara variabel bebas terhadap variabel terikat dengan rumus sebagai berikut:

$$
Y=\beta 0+\beta 1 X 1+\beta 2 X 2+\beta 3 X 3+\varepsilon
$$

Y adalah variabel dependen yang diramalkan Lnbo adalah Kontanta, $b_{1}, b_{2}$,dan $\mathrm{b}_{3}$ adalah koefisien regresi, dan $\mathrm{X}_{1}, \mathrm{X}_{2}$, dan $\mathrm{X}_{3}$ adalah variabel independen). Analisis regresi berganda digunakan untuk menentukan seberapa besar pengaruh simultan antara variabel bebas terhadap variabel terkait dari hasil dengan rumus sebagai berikut :

$\mathrm{Y}=4.660,29-3,090 \mathrm{X} 1+2,659 \mathrm{X} 2+5,193$ $\mathrm{X} 3+\varepsilon$

Dari Hasil Regresi Linear Berganda Menunjukan :

1. Nilai Konstan adalah 4.660,29 menyatakan walaupun harga cabai, cabai keriting, bawang merah 0 konsumsi/permintaan cabai $4.660 \mathrm{Kg}$, harga barang pelengkap dan harga barang pengganti mempengaruhi harga cabai 4.660.

2. Koefisien regresi X1 adalah $-3,090$ menyatakan bahwa setiap penambahan $1 \mathrm{Kg}$ pada cabai yang diminta akan mengakibatkan penurunan harga sebesar 3,09 rupiah.

3. Koefisien regresi X2 sama dengan 2,659 menyatakan bahwa setiap penambahan $1 \mathrm{Kg}$ cabai yang diminta akan meningkatkan harga cabai keriting sebesar 2,65 rupiah.

4. Koefisien regresi X3 adalah 5,193 menyatakan bahwa setiap penambahan $1 \mathrm{~kg}$ pada cabai yang diminta akan meningkatkan harga bawang merah sebesar 5,193 rupiah.

Dapat disimpulkan bahwa banyaknya permintaan memiliki pengaruh terhadap harga cabai merah keriting sebesar 5,193\% dibandingkan harga komoditas utama cabai rawit sebesar 3,09\%.

\section{Koefisien Determinasi $\left(\mathbf{R}^{2}\right)$}

Dari hasil pengujian menggunakan SPSS 21,0 dapat dilihat bahwa nilai $\mathrm{R}^{2}$ adalah 0,628 yang berarti variabel $\mathrm{X}_{1}, \mathrm{X}_{2}, \mathrm{X}_{3}$ berpengaruh sebesar $62,8 \%$ terhadap permintaan cabai rawit dan sisanya $37,2 \%$ 
seperti pendapatan dan jumlah penduduk di pengaruhi oleh faktor lain yang tidak termasuk pada penelitian ini, seperti pada tabel berikut.

Tabel 9. Hasil Output Koefisien Korelasi Berganda (R2)

\begin{tabular}{ccccc}
\hline Model & $\mathrm{R}$ & $\begin{array}{c}\mathrm{R} \\
\text { Square }\end{array}$ & $\begin{array}{c}\text { Adjusted } \\
\mathrm{R} \\
\text { Square }\end{array}$ & $\begin{array}{c}\text { Std. Error of } \\
\text { Estimate }\end{array}$ \\
\hline 1 &, $792^{\mathrm{a}}$ &, 628 &, 526 & 71509,67019 \\
\hline
\end{tabular}

a. Predictors: (Constant) $X_{3}, X_{2}, X_{1}$

\section{Uji F}

Uji $F$ digunakan untuk mengetahui apakah variabel bebas yang di teliti secara bersama-sama berpengaruh tehadap variasi permintaan cabai rawit di Kota Tomohon.

Tabel 10. Hasil Output ANOVAa ( Uji F)

\begin{tabular}{lccccc}
\hline Model & Sum Of Squares & Df & Mean Squares & F & Sig. \\
\hline 1 Regresion & 94810037759,479 & 3 & 31603345919,826 & 6,180 &, $010^{\mathrm{b}}$ \\
Residual & 56249962240,521 & 11 & 5113632930,956 & & \\
\hline Total & 151060000000,000 & 14 & & & \\
\hline
\end{tabular}

a. Dependent Variabel: Y

b. Predictors: (Constant). $\mathrm{X}_{3}, \mathrm{X}_{2}, \mathrm{X}_{1}$

Berdasarkan Tabel 10 dapat diketahui bahwa nilai $\mathrm{F}$ hitung sebesar 6,180 memiliki probabilitas 0,001 pada taraf kepercayaan 99\%. Dengan demikian maka Ha di terima dan Ho di tolak, yang berarti bahwa variabel bebas yang diteliti secara bersama-sama berpengaruh nyata terhadap permintaan cabai rawit di Kota Tomohon. Ini berarti bahwa variabel harga cabai merah keriting, dan harga bawang merah, berpengaruh nyata terhadap permintaan cabai rawit di Kota Tomohon.

\section{Uji T}

Uji - $\mathrm{t}$ adalah uji yang dilakukan untuk mngetahui pengaruh variabel bebas (harga cabai rawit, harga cabai merah keriting, dan harga bawang merah) yang di teliti secara individual terhadap permintaan cabai rawit di Kota Tomohon.
Tabel 11. Hasil Pengujian Parsial ( Uji T ) Coefficients a

\begin{tabular}{|c|c|c|c|c|c|}
\hline \multirow{2}{*}{ Model } & \multicolumn{2}{|c|}{ Sum Of Squares } & \multirow{2}{*}{$\begin{array}{c}\text { Standartdized } \\
\text { coeffisients }\end{array}$} & \multirow{2}{*}{$\mathrm{T}$} & \multirow{2}{*}{$\mathrm{Sig}}$. \\
\hline & B & Std. Error & & & \\
\hline 1 (Constant) & 4660,293 & 104079,355 & & 0,448 & 0,663 \\
\hline $\mathrm{X}_{1}$ & $-3,090$ & 1,070 & -560 & $-2,888$ & 015 \\
\hline$X_{2}$ & 2,659 & 1,967 & 257, & 1,352 & 204, \\
\hline$X_{3}$ & 5,193 & 2,450 & ,408, & 2,120 & ,058, \\
\hline
\end{tabular}

a. Dependent Variabel : Y

Dari hasil analisis Uji T di ketahui bahwa variabel harga cabai merah keriting berpengaruh nyata terhadap permintaan cabai rawit di Kota Tomohon, sedangkan variabel bawang merah juga berpengaruh nyata pada permintaan cabai rawit di Kota Tomohon.

\section{KESIMPULAN DAN SARAN}

\section{Kesimpulan}

Penelitian mengenai faktor-faktor yang mempengaruhi harga cabai rawit di Kota Tomohon kesimpulan sebagai berikut:

1. Permintaan cabai di Kota Tomohon yang relatif tinggi dapat di sebabkan oleh faktor ekonomi dan sosial. Dimana faktor ekonomi yang mempengaruhi adalah (harga cabai itu sendiri dan harga barang lain yang dapat menjadi pengganti atau penggenapnya), sedangkan faktor sosial yang mempengaruhi permintaan adalah jumlah penduduk.

2. Berdasarkan hasil analisis regresi, uji $f$, dan uji t dapat disimpulkan bahwa variabel bebas yang meliputi harga cabai rawit, harga cabai merah keriting sebagai bahan pengganti, dan harga bawang merah sebagai bahan pelengkap secara bersama-sama berpengaruh nyata pada permintaan cabai rawit di Kota Tomohon.

\section{Saran}

Permintaan Cabai Rawit di Kota Tomohon yang berfluktuatif disebabkan oleh pstok cabai rawit yang terbatas, sedangkan konsumsi masyarakat cenderung meningkat seiring bertambahnya jumlah penduduk, selain pasokan cabai yang terbatas dapat menyebabkan naiknya permintaan harga cabai rawit. 


\section{DAFTAR PUSTAKA}

Antara, Made. 2009. Pertanian, Bangkit atau Bangkrut?. Arti Foundatiom Denpasar. Artikel diakses tanggal 9 Januari 2018.

Prajnanta, Final. 2004. Agribisnis Cabai Hibrida. Penebar Swadaya. Jakarta

Sentosa, P.B dan Ashari, 2005. Analisis Statistik dengan Microsoft Excel \& SPSS, ANDI, Yogyakarta. Setiadi. 2008. Bertanam Cabai (Edisi Revisi). Cetakan XXV. Jakarta: Penebar swadaya

Sugiyono, 2012. Metode Penelitian Bisnis, CV Alfabeta, Bandung. 